\title{
DETECTION OF THE PRESENCE OF MICROORGANISMS DURING PRODUCTION OF PLASTERBOARD
}

\author{
Hana Sekavováa ${ }^{a, b, *}, Z_{\text {DenĚK ProšeK }}^{a}$, Pavla Ryparová $^{a}$ \\ ${ }^{a}$ Czech Technical University in Prague, Faculty of Civil Engineering, Department of Mechanics, Thákurova 7 , \\ 16629 Prague 6, Czech Republic \\ ${ }^{b}$ KNAUF Praha spol. s r.o., Mladoboleslavská 949, 19700 Prague 9, Czech Republic \\ * corresponding author: hana.sekavova@fsv.cvut.cz
}

\begin{abstract}
This article is focused on detection microorganisms appearing during production of gypsum plasterboards. The research is carried out within the project TAČR ZÉTA TJ02000235 Sádrokarton se zvýšenou odolností proti bilogické degradaci (Gypsum plasterboard with increased biodegradation resistance). This article shows first part of this issue what was detection of the most critical place of production, where is the highest risk of bacterial contamination and it open the area to find suitable modification of production process or recipes of gypsum plasterboards.
\end{abstract}

KEYWORDS: Gypsum plasterboard, microorganism, mold, stucco.

\section{INTRODUCTION}

Gypsum plasterboard is basically a composite material that consists primarily of a gypsum core and paper. It is the most widely used element of dry construction, which spread in Europe in the 1970s. There was a massive expansion of this type of construction in the early 1990s in the Czech Republic, when imported gypsum boards from neighboring countries first began to appear on the market, and in the mid-1990s, gypsum boards produced domestically [1]. The term dry construction, of course, includes not only plasterboard, but also other types of building boards and they of course include accessories for their assembly - profiles, screws, sealants, etc.

The research of detection of the presence of microorganisms during production of plasterboard has two main targets. The first one is find solution for presence molds during storage, construction and use and the second one is prevention of mold during storage of waste before recycling and its subsequent introduction back into production process.

Recycling in general has been a much-discussed and supported topic with regard to sustainable development in recent years. Research in the field of concrete recycling is very popular, but even gypsumbased building elements are not left behind. The recycling of gypsum itself is, by its nature, simple and repeatable. It is only a conversion of calcium sulphate dihydrate to its hemihydrate and back again. Recyclability in the case of gypsum plasterboard is partially limited by the carton and other components added to the gypsum slurry, which reduce the purity of the calcium sulphate and some fundamentally affect the rehydration behavior. The information about the effect of the use of recycled material based on gypsum on the properties are mentioned in tasks from years 2018 and $2019[2,3]$.
Influence of living organism to buildings, therefor building materials has many aspects. What can we observe at first sight is esthetic damage, but there is also mechanical damage and health effect [4]. That is the reason why there is lot of researches focus on this topic in many researches.

The influence of the microoraganisms what occupied the building parts is very time solved topic. From many of them is popular detection and solution for ETICS [5, 6] and last but not least problematic with organism in wood construction [7]. With plasterboards have these topics similar base - stucco and gypsum like binder and paper like a product of wood.

The target of this research is find the most critical place of production, where is the highest risk of bacterial contamination.

\section{MATERIAL}

At the beginning of this research was detected places and materials across the Plant Počerady. The schema of production of plasterboards is showed on Figure 1.

Place No.1 is unwinding of bottom paper (face side paper). No.3 is unwinding of upper paper (backside paper). Position No.2 shows main mixer preceded by preparatory station of dry and wet component. All components are mixed in main mixer and gypsum slurry is put between bottom and upper paper and this slurry together with paper continues through forming table to the setting (No.4). The gypsum slurry hardens on the setting belt. The important feature of this wet belt of product is possibility to cut. The cut is made on knife (No.5), where is cut the endless belt of plasterboard product on the individually boards. The boards are completed and transport by cross conveyor and turner (No.6) to tipple (No.7), which distributes the boards to dryer (No.8). The dryer has 8 floors and standard boards are dried in 


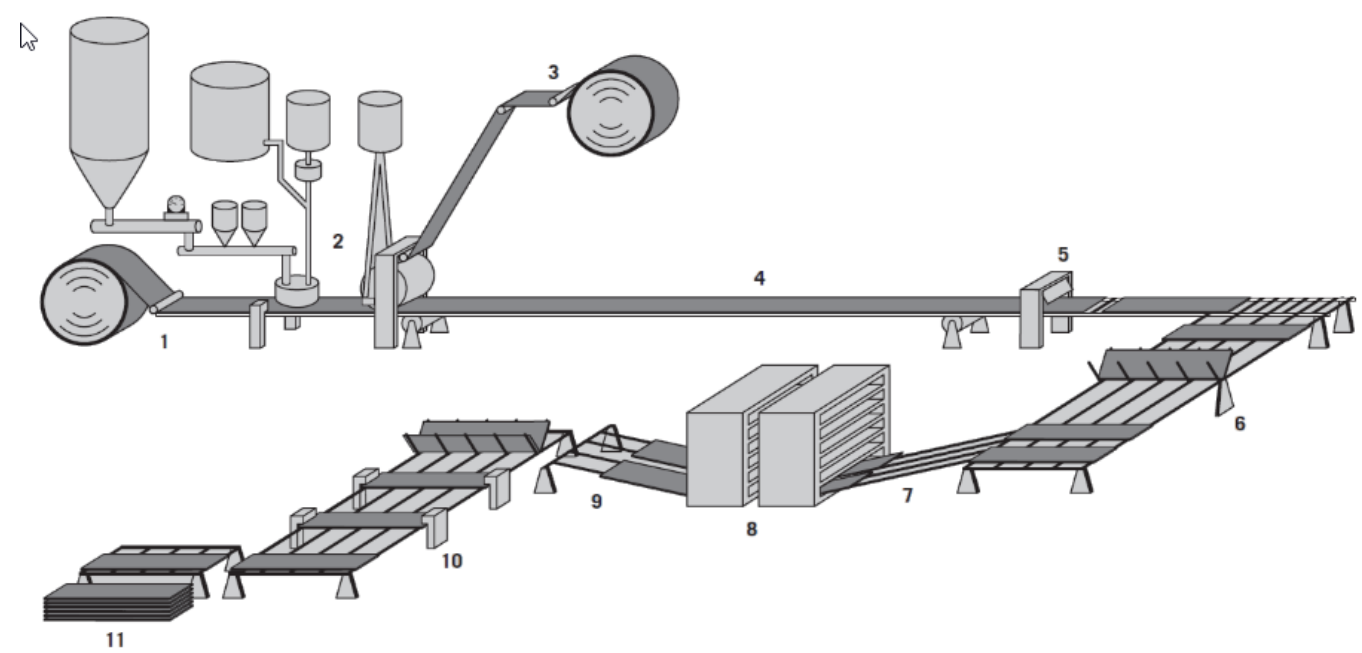

Figure 1. Schema of production of plasterboards.

\begin{tabular}{ll}
\hline Sample & Identified microorganisms \\
\hline Paper pulp & Sphingomonas paucimobilis, Pseudomonas aeruginosa \\
Process water & Pseudomonas aeruginosa, Penicillium sp. \\
Gypsum plasterboard & Stenotrophomonas maltophilia, Penicillium sp., Mucor \\
Stucco & Penicillium sp. \\
\hline
\end{tabular}

TABLE 1. Identification of the samples used to determine the resistance of the materials.

two lines. Počerady plant has dryer which is consist of prezone, 1st zone, 2nd zone and the cooling section. During way through the dryer is evaporated all of not necessary water. The temperature of gypsum core has to be under $100{ }^{\circ} \mathrm{C}$ all the time.

Boards are transported after dryer by tipple (No. $9)$ to turner and they are completed on turner and they continue to bundler (No. 10), where are boards cut (possibly mill) to final dimension (beveling). The last process is assembly of plasterboards on transport pallets (No.11).The boards then travel to the finished goods warehouse

The samples of input raw materials and final products were collected in the period from March to June 2019. The sampled plasterboards were two main products Knauf WHITE and KNAUF Green. Knauf WHITE is the gypsum plasterboard Type A. It is plasterboard with a face to which suitable gypsum plasters or decoration may be applied. Knauf GREEN is the gypsum plasterboard Type H. It is plasterboard with reduced water absorption rate. These boards are produced with additeves to reduce the water absorption rate and they may be suitable for special applications in which reduce water absorption properties are required to improve the performance of the board [8]. Knauf GREEN has total water absorption under $10 \%$ and it fulfill the category H2 according to Eurepean Standard EN 520.

The main products for production of plasterboards are stucco, water and paper. Stucco is calcinated of FGD Gypsum, which is produced during desulphuri- sation process in power plant. Process water is filtrated surface water.

Input raw materials, what were sampled, were stucco, FGD Gypsum, process water, paper pulp and paper. Intermediate were gypsum slurry (after the mixer) and wet board (cut at knife, before drying process).

\section{EXPERIMENTAL METHODS AND RESULTS}

\subsection{Determination of a Consortium of MICROORGANISMS}

Identification of microorganisms was performed microscopically according to significant features on suitable media and according to their enzyme properties using commercial kits.

Enriched medium Total agar (Oxoid) was used to identify bacteria. Cultivation was performed at $30{ }^{\circ} \mathrm{C}$ for 48 hours. Molds were identifiable after culturing on Czapek Dox agar (Oxoid) at $25{ }^{\circ} \mathrm{C}$ for three to seven days.

Similar microorganisms occur throughout the production process and therefore a specific source of contamination cannot be clearly identified.

The most likely source of mold is the free flow of air and the movement of people and vehicles between the outdoor area and the production hall.

The largest source of bacteria is pulp and process water. Similar microorganisms were found in the air 

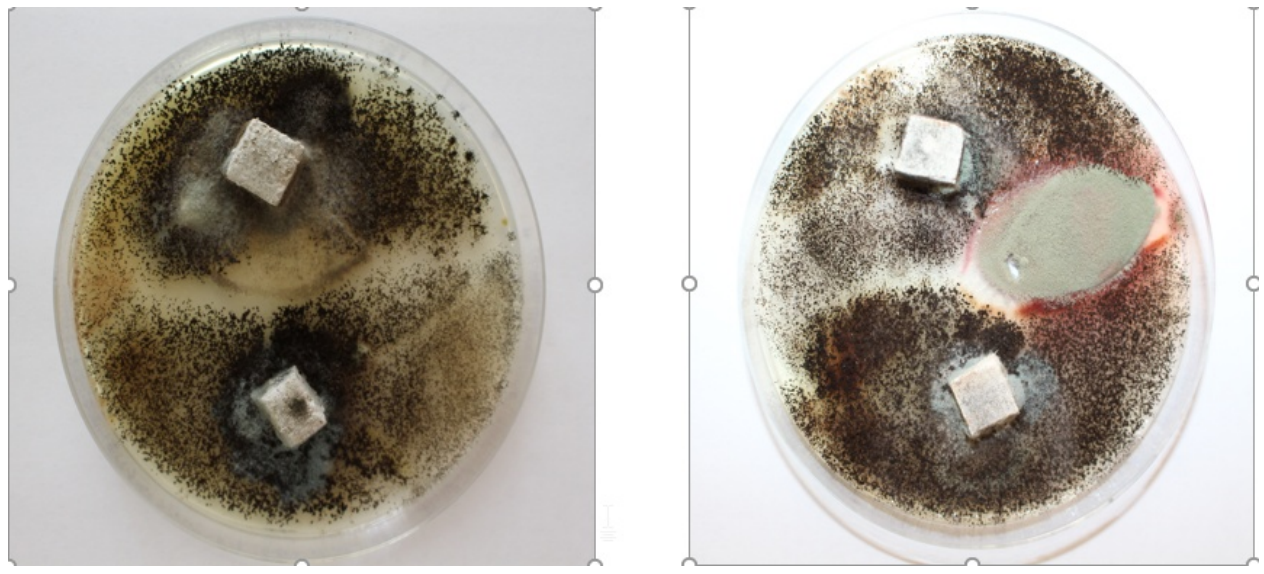

FIGURE 2. Identification of naturally occurring molds.

\begin{tabular}{cl}
\hline Sample & Kind of sample \\
\hline 1 & Gypsum plasterboard Type H with paper \\
2 & Gypsum plasterboard Type H without paper \\
3 & Gypsum plasterboard Type A with paper \\
4 & Gypsum plasterboard Type A without paper \\
5 & Gypsum slurry (hardened) Type H \\
6 & Gypsum slurry (hardened) Type A \\
7 & Gypsum labor slurry - (stucco + water; hardened) \\
8 & Paper green \\
9 & Paper white \\
\hline
\end{tabular}

TABLE 2. Identification of the samples used to determine the resistance of the materials.

and on the surface of the production line, but their amount is negligible. Results are showed in Table 1.

The designation of the samples in the microbiological study is given in the following Table 2 .

Individual materials were contaminated with molds of the genus Penicillium, Aspergillus and Mucor. These molds were also found on the samples taken in production process. The highest contamination was detected in materials with paper (sample 1 and sample 3 ). The Figure 2 shows identification of naturally occurring molds.

\subsection{Monitoring MATERIAL DEGRADATION}

Microbial degradation was performed according to the standard ISO EN 846 [9] that determines the degree of resistance of the material to the occurrence of molds (determines their resistance to biodegradation). The samples were $1 \times 1 \mathrm{~cm}$ in size, their height depended on type of material. Sterilization was performed using UV radiation, when microorganisms were deactivated from the surface while maintaining material and chemical parameters of individual samples. Sterilization methods degrading the original properties of the material was not used. Samples were inoculated with a consortium of molds and then placed at $25 \pm 3{ }^{\circ} \mathrm{C}$ and monitored for 41 days. The consortium of fungi contained microorganisms from the Czech collection of microorganisms:
Paecilomyces variotti, Chaetomyum globosum, Penicillium funiculosum, Aspergillus terreus, Penicillium brevicompactum. The evaluation of the resistance of the material took place visually on the $14 \mathrm{th}, 22 \mathrm{nd}$, 29 th and 41st day.

Sample 1 has isolated colonies of molds after 14 days of experiment. On day 22, coverage was already $80 \%$ and more (Figure 3 ).

Sample 2 is very resistant to mold. The samples showed isolated mold hyphae, but they grew more out of the medium. At the end of the experiment, fungi were visible at the bottom of the flanks and isolated colonies of mold at the top (Figure 4).

Mold colonies were already visible on day 14 on sample 3 and on day 22 the samples were completely covered (Figure 5).

Sample 4 was the most resistant to the occurrence of mold, after 41 days only isolated colonies of mold were visible on the surface, the sides of the samples were only partially covered (approximately $30 \%$ ). The mixture of sample 5 had a similar result, only the coverage rate after 41 days was several percent higher (Figure 6).

Sample 6 had almost the entire sides covered and mold colonies were already present on the surface on day 22. The coverage rate remained almost unchanged by the end of the experiment. Sample 7 prevented the growth of mold until day 41, where iso- 


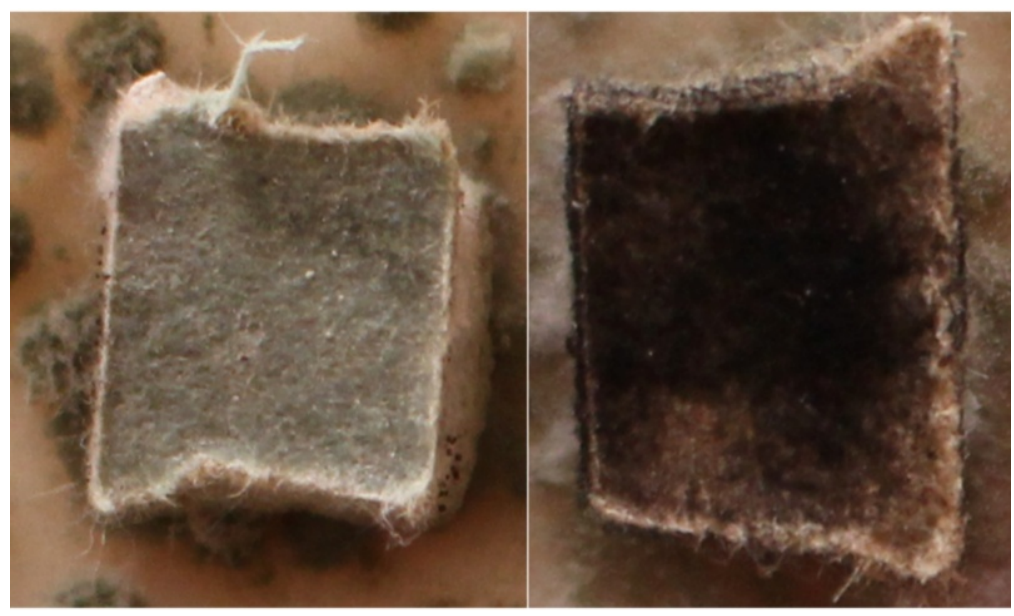

FIguRE 3. Sample 1 after 14 (left) and 22 (right) days.

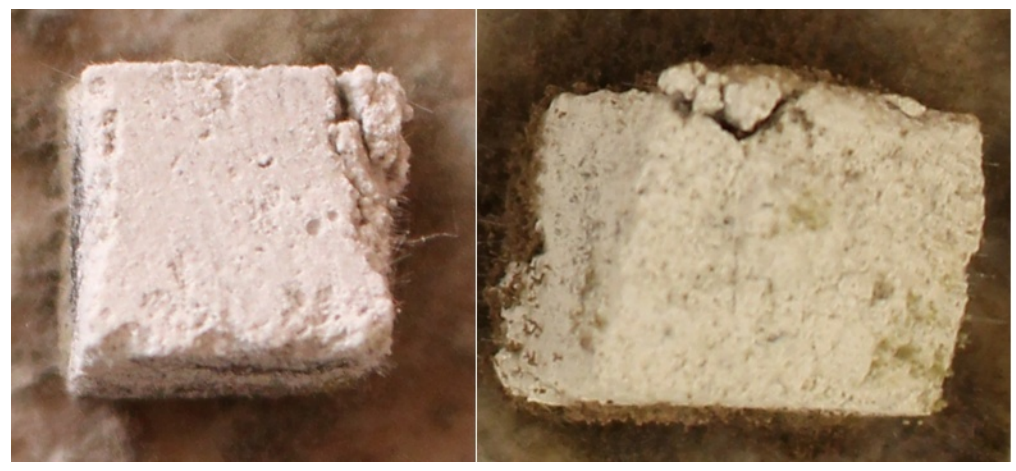

Figure 4. Sample 2 after 25 (left) and 41 (right) days.

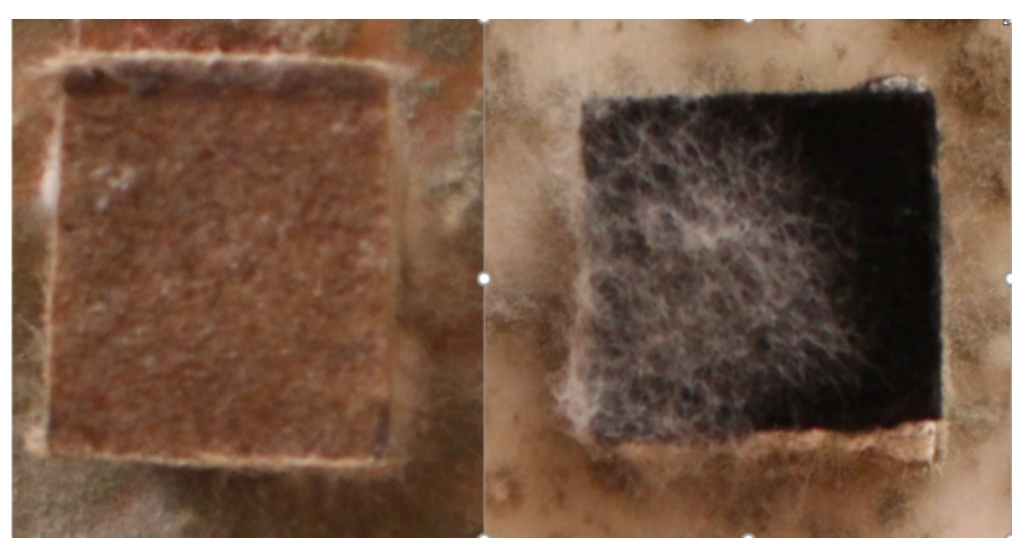

Figure 5. Sample 3 after 11 (left) and 25 (right) days.

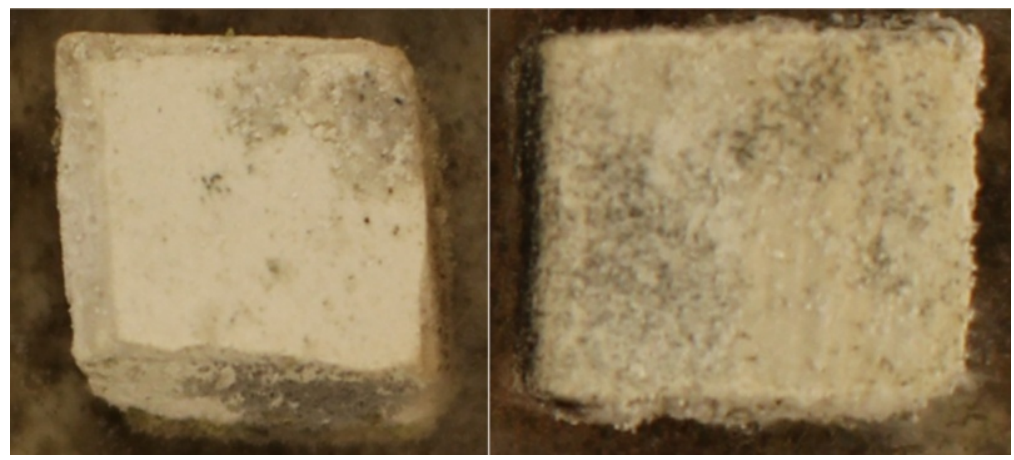

Figure 6. Sample 4 (left) and sample 5 (right) after 41 days. 


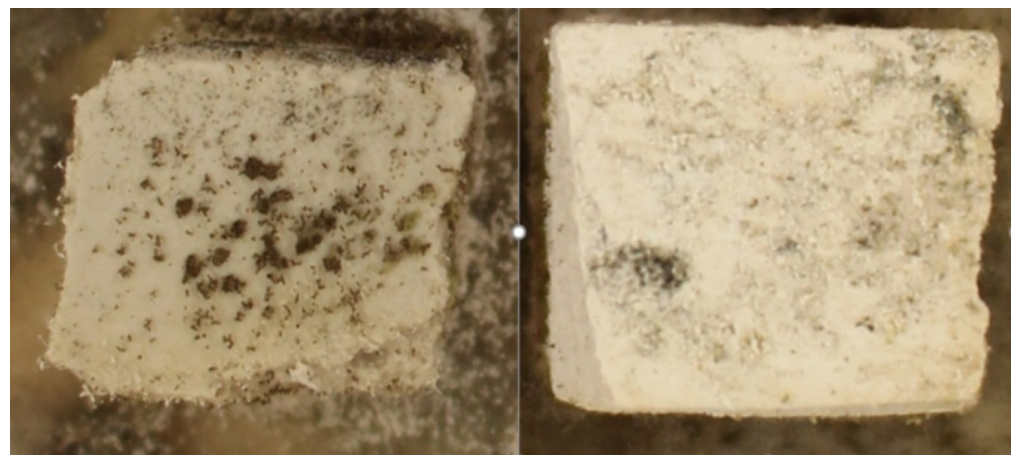

Figure 7. Sample 6 (left) and sample 7 (right) after 41 days.

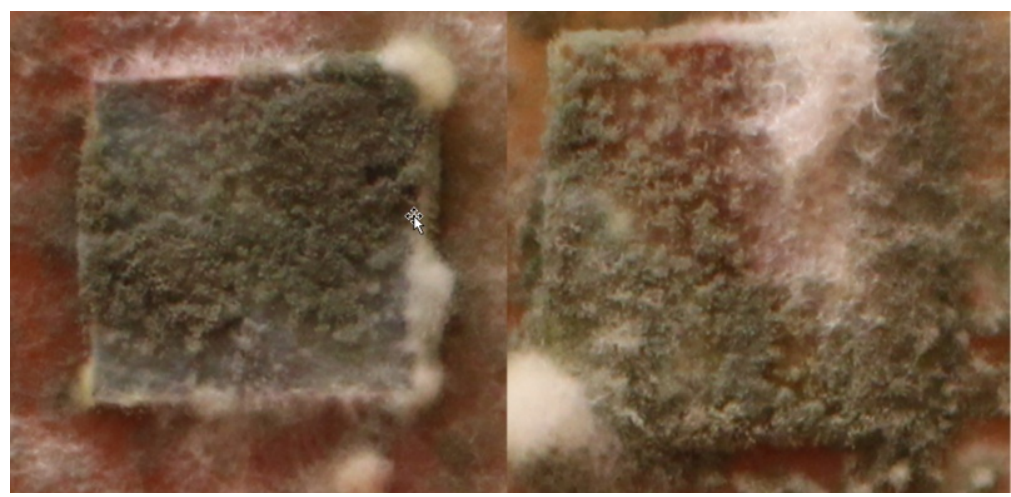

Figure 8. Sample 8 (left) and sample 9 (right) after 11 days.

lated colonies were visible, both on the surface and on the sides (Figure 7). Paper samples were most prone to mold growth and growth began as early as the first week (Figure 8).

\section{Conclusions}

From the above results it is clear that the most risky part of gypsum plasterboards is the paper part. The best results achieve the samples of hardened gypsum slurry type $\mathrm{H}$ (impregnate) and hardened gypsum slurry prepared in laboratory from stucco and water.

The experiment was designed to simulate a very demanding environment and in the case of the use of these materials in real constructions, the time of microbial contamination depends on the conditions, which are humidity, temperature and possible pollution as a source of nutrients for microorganisms.

These results are the basis for subsequent modifications to prevent the development of microorganisms in gypsum plasterboard systems.

\section{ACKNOWLEDGEMENTS}

This paper was financially supported by the TA CR research a project under the number TJ02000235 and by Czech Technical University in Prague under No. SGS project SGS19/148/OHK1/3T/11. The authors also thank Knauf, Praha Ltd. for the supplied samples and materials and the Center for Nanotechnology in Civil Engineering at the Faculty of Civil Engineering, Czech Technical University in Prague.

\section{REFERENCES}

[1] M. Nyč. Sádrokarton. Grada Publishing as, 2005.

[2] J. Herrmann. Možnosti recyklace výrobkŭ na bázi sádry 2019 .

[3] H. Sekavová, J. Herrmann, Z. Prošek, et al. The influence of the use of recycled gypsum on the properties of gypsum products in labor conditions. Acta Polytechnica CTU Proceedings 26:81-85, 2020.

[4] R. Wasserbauer. Biologické znehodnocení staveb [biological damage of structures]. ABF ARCH: Praha, Prague 2000.

[5] N. Antošová. Impact of biocorrosion on the durability of etics and empirical findings about the periodocity of maintenance. Slovak Journal of Civil Engineering 21(2):21-28, 2013.

[6] V. Kučeriková, M. Kraus, D. Kubečková. Analysis of the degradation of external plasters in the buildings with etics. In Advanced Materials Research, vol. 1041, pp. 15-18. Trans Tech Publ, 2014.

[7] M. Havrlik, P. Ryparová. Protection of wooden materials against biological attack by using nanotechnology. Acta Polytechnica 55(2):101-108, 2015.

[8] ČSN EN 520+A1. Sádrokartonové desky - Definice, požadavky a zkušební metody. Praha: Úřad pro technickou normalizaci, metrologii a státní zkušebnictví 2010.

[9] ČSN EN ISO 846. Plasty - Hodnocení působení mikroorganismů. Praha: Úrad pro technickou normalizaci, metrologii a státní zkušebnictví 2019. 